\title{
Article 27 of the CRPD and the Right of Inclusive Employment of People with Autism
}

\author{
Marco Fasciglione
}

\section{Introduction}

According to global estimates, persons with disabilities constitute some $15 \%$ of the world's population. Between 785 million and 975 million of them are of working age $(15 \text { years or older })^{1}$ and most live in developing countries where the informal economy employs a substantial proportion of the labour force. The labour force participation rate of persons with disabilities is low in many countries. Recent figures for members of the Organization for Economic Co-operation and Development indicate that slightly less than half of working-age persons with disabilities were economically inactive compared to one in five persons without disabilities of working age. $^{2}$ While it is difficult to draw comparisons between countries on rates of unemployment due to national differences in definitions on disability and statistical methodology, it is clear that an employment gap exists across countries and regions. As far as the EU, unemployment rate of persons with disabilities in the 2011 was at $17.4 \%$, a data lower than 2010 (when it was at $18.0 \%$ ), but however very far from the unemployment rate of persons without disabilities for the same year (at 10.2\%). ${ }^{3}$

Indeed, when persons with disabilities are employed, they are more likely to be situated in low-paying jobs, at lower occupational levels and with worst working conditions than their colleagues. More often than their peers, they are in part-time jobs or temporary positions, often with few possibilities for career development.

\footnotetext{
${ }^{1}$ See World Health Organization and the World Bank (2011), p. 261. For all websites, last access 30 October 2014.

2 Ibid., p. 237.

${ }^{3}$ Data are drawn by the Report on the implementation of the UN Convention on the Rights of Persons with Disabilities (CRPD) by the European Union, SWD(2014) 182 Final, p. 62.

M. Fasciglione ( $\square)$

Institute for International Legal Studies (ISGI-CNR), Naples, Italy

e-mail: marco.fasciglione@cnr.it
} 
The obstacles that such persons face in this regard are often related to negative attitudes or opinions, deeply rooted stigma and stereotypes and lack of interest of governments, employers and the general population. Lack of access to education and training in skills relevant to the labour market are also major barriers. Persons with disabilities are often seen as unfit for working life, incapable of carrying out tasks, as required in the open labour market, or better off in protected environments such as sheltered workshops. Worst data there exist as to the specific category of persons with autism spectrum disorder (ASD). Indeed, less than $10 \%$ of people with ASD can get a job compared with $45 \%$ of those with a disability, and $65.8 \%$ of people without a disability.

\section{The Right to Work and to Employment of Persons with Disability: Article 27 of the CRPD}

The protection of the rights of persons with disabilities is since long a challenge for international community, and at the very least, as far as the employment sphere, since the International Labour Organization (ILO) Convention no. 159 concerning Vocational Rehabilitation and Employment of Disabled Persons (1983). However, it is only with the United Nations Convention on the Rights of Persons with Disabilities (hereinafter CRPD) that a coherent and complete protection of rights of persons with disabilities has been foreseen. Article 27 of the Convention sets out the right to work of persons with disabilities: it constitutes one of the most detailed provisions of the Convention, establishing the legal framework for State obligations in relation to work and employment of persons with disabilities. ${ }^{4}$

Article 27 (1) of the Convention obligates States parties to recognize the right of persons with disabilities to work, on an equal basis with others. It develops the provision of Article 23 of the Universal Declaration of Human Rights and employs similar language to that of Article 6 of the International Covenant on Economic, Social and Cultural Rights. ${ }^{5}$ It states that the right of persons with disabilities to work includes the right to the opportunity to gain a living by work freely chosen or accepted in a labour market and work environment that is open, inclusive and accessible to persons with disabilities and sets out a non-exhaustive list of appropriate steps for States parties to take, including through legislation, to safeguard and promote the realization of the right to work, including for those who acquire a disability during the course of employment. ${ }^{6}$

\footnotetext{
${ }^{4}$ The Convention was adopted by the United Nations General Assembly on 13 December 2006 and entered into force on 3rd May 2008 together with its Optional Protocol. The CRPD is the first United Nations human rights treaty to be adopted in the twenty-first century and is reputed to be the most rapidly negotiated ever. On the Convention, see Hendricks (2007), Lawson (2007), Kayess and French (2008), and Flynn (2011).

${ }^{5}$ See the Committee on Economic, Social and Cultural Rights' general comments No. 5 (1994) on persons with disabilities and No. 18 (2005) on the right to work.

${ }^{6}$ See Convention on the Rights of Persons with Disabilities, Article 27 (1) (a) to (k).
} 
The right of persons with disabilities to work involves an obligation on the part of States parties to create an enabling and conducive environment for employment, in both the public and private sectors.

Article 27 of the Convention guides States parties in the implementation of the right of persons with disabilities to work by setting forth some basic rules: (a) nondiscrimination, as the persons with disabilities have the right to work on an equal basis with others; (b) accessibility, as the right of persons with disabilities to work includes the opportunity to gain a living in a work environment that is accessible to persons with disabilities, identifying and removing barriers that hinder persons with disabilities from carrying out their work on an equal basis with others ${ }^{7}$; (c) reasonable accommodation, as with a view to facilitating access of persons with disabilities to work on an equal basis with others, States parties must ensure that reasonable accommodation is provided to persons with disabilities who request it, and should take effective steps, including through legislation, to ensure that the denial of reasonable accommodation constitutes discrimination; (d) besides a duty to impose obligations on private-sector employers, States should adopt positive measures to promote employment opportunities for persons with disabilities.

These standards, therefore, impose different levels of obligations on States: more in particular from one side States are obliged to abstain from infringing rights of persons with disabilities, and from another side the Convention requires them to adopt positive measures to promote employment opportunities for persons with disabilities and this especially with regard to private-sector employers.

Amongst the implementation measures that States parties should take on the basis of the Convention a pivotal role is played by the duty of aligning national standards and practice to the Convention. In this respect, Article 4 (1) (a) and (b) of the Convention imposes two general obligations on States parties; namely: (a) to adopt all appropriate legislative, administrative and other measures for the implementation of the rights recognized in the Convention related to work and employment; (b) to take all appropriate measures, including legislation, to modify or abolish laws, regulations, customs and practices that constitute discrimination against persons with disabilities in the areas of work and employment.

\footnotetext{
${ }^{7}$ According to the Committee '[p]ersons with disabilities cannot effectively enjoy their work and employment rights, as described in article 27 of the Convention, if the workplace itself is not accessible. Workplaces therefore have to be accessible, as is explicitly indicated in article 9, paragraph 1 (a)' and '[a] refusal to adapt the workplace constitutes a prohibited act of disability-based discrimination' (see the CRPD Committee, General Comment No. 2 (2014), Article 9: Accessibility, UN DOC. CRPD/C/GC/2, 22 May 2014, para 41).
} 


\subsection{The Prohibition of Discrimination in the Workplace}

The general principle of non-discrimination applies to employment as to all other sphere of life and the prohibition of discrimination against persons with disabilities is one of the main pillars of the CRPD. Indeed, discrimination on the basis of disability is defined in Article 2 of the Convention as 'any distinction, exclusion or restriction on the basis of disability which has the purpose or effect of impairing or nullifying the recognition, enjoyment or exercise, on an equal basis with others, of all human rights and fundamental freedoms in the political, economic, social, cultural, civil or any other field...'. According to this provision this definition 'includes all forms of discrimination, including denial of reasonable accommodation'. From this perspective, while the full realization of economic, social and cultural rights, including the right to work, is subject to the principle of the progressive realization, ${ }^{8}$ the prohibition of discrimination on the basis of disability is an obligation with immediate effect. States parties have an obligation to prohibit discrimination on the basis of disability and must ensure that persons with disabilities are protected from discrimination, ${ }^{9}$ including with regard to all matters concerning all forms of employment ${ }^{10}$ as in any other area.

What is important to stress here is the circumstance that the protection of discrimination covers all forms of employment: in the open labour market as well as in sheltered or supported employment schemes. In effect, the prohibition of (both de jure and de facto) discrimination should cover all aspects of employment, including, but not limited to, the following: recruitment processes such as advertising, interviewing and other selection processes; review of hiring standards to remove indirect discrimination that places persons with disabilities at a disadvantage; recruitment decisions; terms and conditions of employment such as remuneration rates, work hours and leave; promotion, transfer, training or other benefits associated with employment, or dismissal or any other detriment, such as demotion or retrenchment; benefits related to the (non-discriminatory) termination of employment; victimization and harassment; safe and healthy working conditions.

\footnotetext{
${ }^{8}$ See Article 4 (2) of the Convention echoing the content of Article 2 (1) of the International Covenant on Economic, Social and Cultural Rights. As far as the application of the progressive realization principle and the necessity to assuring that economic constraints do not involve infringements of basic economic social and cultural rights of marginalized and less favoured individuals of the society see Fasciglione (2014).

${ }^{9}$ See Article 5 (2).

${ }^{10}$ See Article 27, para 1 (a).
} 


\subsection{Accessibility to Workplace}

It is well-established that accessibility is both a general principle and a substantive provision of the CRPD ${ }^{11}$ and applies to workplaces (both public-sector workplaces and private-sector employers) as to all other spheres of life. States are required to take steps towards ensuring a fully accessible workplace: this obligation is crucial for removing the various barriers-physical, attitudinal, information-, communication- or transport-related - that prevent persons with disabilities from seeking, obtaining and maintaining work. Physical barriers such as inaccessible public transport, housing and workplaces are often among the main reasons why persons with disabilities are not employed. The simple fact that a workplace is not accessible does not justify the failure to employ persons with disabilities. ${ }^{12}$ States have to inform employers-irrespective of size or sector-about their positive obligation to identify barriers to equal access to the workplace by persons with disabilities and to take appropriate steps towards removing such barriers. Good practices to this end include awareness-raising efforts among employers on the need to implement regulations relating to the creation of a barrier-free, disability-friendly environment, and the development of guidelines on accessibility and universal design for employer.

\subsection{The Principle of Reasonable Accommodation as a General Rule of the CRPD and as a Specific Standard to Be Applied in the Workplace}

The Convention includes the duty to provide reasonable accommodation, ${ }^{13}$ as defined in Article 2. According to this definition 'reasonable accommodation' has to be meant as the 'necessary and appropriate modifications and adjustments not imposing a disproportionate or undue burden, where needed in a particular case, to

\footnotetext{
${ }^{11}$ See Article 9 of the Convention.

${ }^{12}$ State practice reveals that many countries have taken steps to make workplaces accessible for persons with disabilities, including through legislative and policy measures. Most countries have taken action towards promoting physical accessibility, including through building ramps, accessible toilets, elevators providing sign language interpretation for deaf applicants in interviews, or legislating at national level that accessibility must be ensured in both private and public sector workplaces with more than a certain number of employees.

${ }^{13}$ The concept of reasonable accommodation was introduced in the United States of America 1968 Civil Rights Act and subsequently applied in the Americans with Disabilities Act of 1990; comparable legislation in the United Kingdom of Great Britain and Northern Ireland and in Australia uses the term 'reasonable adjustment'. European Union Council Directive 2000/78/EC states that reasonable accommodation for disabled persons shall be provided in the area of employment (Article 5). Examples of what constitutes reasonable accommodation are included in the WHO (2011), cit., p. 74.
} 
ensure to persons with disabilities the enjoyment or exercise on an equal basis with others of all human rights and fundamental freedoms'. Furthermore, what is important to underpin is the circumstance that according to the CRPD the denial of reasonable accommodation constitutes a discrimination on the basis of disability. It follows that States must ascertain that the duty to ensure reasonable accommodation is introduced in their legislation and anti-discrimination legislation should define denial of reasonable accommodation as a form of discrimination. ${ }^{14}$ The abovementioned provision is reinforced by Article 5(3), which also requires States 'to take all appropriate steps to ensure that reasonable accommodation is provided'. The incorporation of a State obligation to ensure that reasonable accommodations are adopted to facilitate the exercise by persons with disability of CPRD rights is perhaps the most fundamental instrumental element of the Convention. Indeed, such a broad scope to reasonable accommodation sets the Convention apart from its predecessors in international law, directly linking the absence of reasonable accommodation to the perpetuation of discrimination and inequality; furthermore, it affords to State parties the onus to take all appropriate steps to meet the reasonable accommodation requirement. Nevertheless, its formulation, very far from the optimal, may be narrow interpreted and unduly restrict the scope of application of the States' obligations. In effect, the obligation ceases at the point where the adjustment required constitutes a 'disproportionate or undue burden'. In the second place, the terms 'disproportionate' and 'undue burden' have been drafted as additive, effectively creating a two element test that may allow the obligation to be evaded at the lower of either threshold (which may vary according to context). In the third place, the thresholds themselves appear insufficiently challenging to penetrate to the core of exclusionary practices affecting persons requiring significant structural adjustments. They appear more likely to produce results for persons who require relatively marginal changes to the prevailing social environment. Finally, it should be also observed that the terminology 'undue burden' is far from being opportune in that it activates precisely the construction of persons with disability as 'burdens' on the community: an approach that the CPRD otherwise attempts to overcome.

\footnotetext{
${ }^{14}$ Since the beginning of its mandate, the CRPD Committee has consistently urged States parties to establish, including in legislation, that denial of reasonable accommodation constitutes discrimination. As for instance, in its first concluding observations with regard to Tunisia, the Committee instructed the State party to, 'incorporate the definition of reasonable accommodation in national law and to apply it in accordance with article 2 of the Convention, in particular by ensuring that the law explicitly recognises the denial of reasonable accommodation as a disability based discrimination' and that the State party 'act with urgency to include an explicit prohibition of disability-based discrimination in an anti-discrimination law, particularly those governing elections, labour, education and health, among others' (see Committee on the Rights of Persons with Disabilities, Concluding observations: Tunisia, Fifth session 11-15 April 2011, CRPD/C/ TUN/CO/1, 13 May 2011, paras 12-13).
} 


\subsubsection{The Reasonable Accommodation in the Workplace and Its Implementation}

The most prominent application of the reasonable accommodation requirement remains in the field of work and employment. Article 27 of the CRPD requires States Parties to safeguard and promote the realisation of the right to work of persons with disabilities by taking appropriate steps to ensure that reasonable accommodation is provided to persons with disabilities in the workplace. Under the Convention, employers have a legal obligation to provide reasonable accommodation to persons with disabilities. Legislation must stipulate that both publicand private-sector employers are responsible for providing reasonable accommodation to individual employees with disabilities. Governments, hence, should develop policies aimed at promoting and regulating flexible and alternative work arrangements that reasonably accommodate the individual needs of employees with disabilities. Such policies should include, inter alia, adjustment and modification of machinery and equipment, modification of job content, working time and work organization, and adaptation of the work environment to provide access to the workplace, in order to facilitate the employment of individuals with disabilities. The implementation of the principle of reasonable accommodation in national disability-related legislation has been slow in many countries; this is due usually to several factors. In the first place, from the national law level, the notion of reasonable accommodation (an individual requirement) is often confused with accessibility measures (a general requirement) or with positive measure schemes. In the second place, this may be due to the reluctance of employers to recruit persons with disabilities determined by the fear of having to make expensive workplace adjustments. Indeed, a general misconception that all persons with disabilities will need reasonable accommodation or that accommodations will be too costly or difficult to provide, there exists. ${ }^{15}$ With a view to correcting misconceptions, States have the responsibility to inform employers of their duties to provide reasonable accommodation, to raise awareness on the concept among employers, trade unions and persons with disabilities, and to provide technical assistance on how to transform the provision into practice. The determination of what constitutes 'appropriate measures' is essential for the effective implementation of the duty to provide reasonable accommodation. It can be argued that measures are appropriate if they facilitate access to and participation in working life, job advancement and training on an equal footing with others for a person with disabilities requesting them. The identification of appropriate measures must be made on the basis of an individual assessment of the specific job, the needs of the person with a disability and a realistic assessment of what the employer is capable

\footnotetext{
${ }^{15}$ However, many persons with disabilities do not need reasonable accommodation and many accommodations can be provided at little or no cost. Even where required, only accommodation that is reasonable, necessary, appropriate and which does not impose disproportionate or undue burden, is mandated.
} 
of providing. This process should be interactive and participatory to be effective, and all information related to the reasonable accommodation request should be handled with confidentiality.

\subsection{Positive Measures to Promote Employment of Persons with Disabilities}

Besides having a duty to impose obligations on private-sector employers, States have an obligation to take positive measures to increase employment of persons with disabilities in the private sector. The Convention establishes that States parties shall undertake measures to employ persons with disabilities in the public sector, and to promote the employment of persons with disabilities in the private sector through appropriate policies and measures, which may include affirmative action programmes, incentives and other measures (Article 27(1)(h), also (e), (i) and (k)).

Usually, the most common employment promotion scheme tends to be the use of quotas. Most countries have legislation on the percentage of positions in the publicsector for persons with disabilities, and some also have quotas for the private sector, providing for sanctions for non-compliance. ${ }^{16}$ Existing quota systems can be divided into two main categories: strict quotas and flexible quotas. Strict quotas refer to schemes in which a person with a disability is treated preferentially irrespective of whether he or she is as qualified as other applicants. With flexible quotas, an applicant with a disability is treated preferentially only if he or she has equal merits and qualifications as another applicant. States are facing challenges in establishing effective positive measures that adequately advance equal possibilities for persons with disabilities to participate in working life. One concern is that they might send a (negative) message that persons with disabilities are hired solely on the basis of their disability, which can lead to reinforcement of stigma and negation of their role as professionals. For this reason, States are recommended to design

\footnotetext{
${ }^{16}$ In Italy Act n. 68 of 12 March 1999 obliges both public and private employers with at least 15 workers, to hire disabled workers in accordance with reserve quota (see Article 3). This mandatory hiring, limited to new workers and valid for technical/executive staff only, also concerns political parties, trade unions and no-profit associations operating in the field of social solidarity, assistance and rehabilitation. For police services, civil protection and national defence, the placement of persons with disabilities only concerns administrative services. The quota system is enforced also in Austria, Belgium, Cyprus, Ireland, Luxemburg, Malta, France, Germany, Greece, Spain, Romania, and Portugal. Bulgaria and Hungary have a quota system but do not foresee any sanction or penalties as to its enforcement. Norway and the Netherlands do not have any specific recruitment and dismissal rules for people with disabilities. Outside the European regional level, Mauritius has introduced quota system with the Training and Employment of Disabled Persons Act of 1996. The Act requires workplaces with 35 or more employees to set aside at least $3 \%$ of their positions for persons with disabilities. Any employer who contravenes this provision is liable to a compensatory payment payable to the Training and Employment of Disabled Persons Board or to imprisonment (see International Labour Organization 2004, p. 5).
} 
positive measures in such a way that the potential negative element is minimized. The focus of these programmes should be on increasing recognition of the value of diversity in the workplace and equal career development for all. Programmes focusing on promoting employment of persons with disabilities should extend to all persons with disabilities, with a special focus on women and youth with disabilities, persons with intellectual or psycho-social disabilities and other potentially vulnerable groups.

\section{The Implementation of Article 27 CRPD Within the European Regional System}

\subsection{The EU Rights-Based Approach}

The EU accession to the CRPD in $2010^{17}$ ensured that the rights enshrined within the CRPD became part of EU law, albeit only to the extent that the EU has competence in the relevant field. The CRPD is now situated between primary and secondary law in the hierarchy of EU legislation, creating new standards of protection for persons with disabilities for the EU and its Member States. Therefore, the implementation of the rules on work and employment of persons with disabilities fall within European Union competence under two main aspects, at the very least. The EU has shared competence with member States with respect to the implementation of the right to employment and exclusive competence as regards the compatibility of State aid with the common market and the Common Customs Tariff.

As far as the first area of analysis, by the 1990s, the European Commission's Communication on Equality of Opportunity for People with Disabilities: A New European Community Disability Strategy puts the focus firmly on the barriers facing persons with disability, noting that 'our societies are, in many ways, organised for an "average" citizen without any disability, and, therefore, a great number of citizens are excluded from the rights and opportunities of the vast majority'. ${ }^{18}$ It also recognised the need to address disability discrimination far beyond employment, to cover education, mobility and access, housing and welfare systems. Amsterdam amending the Treaty on European Union (Amsterdam Treaty) marked a breakthrough in disability non-discrimination law, enshrining the

\footnotetext{
${ }^{17}$ The CRPD and its Optional Protocol are the first UN human rights treaties to be signed by the European Union. Under Article 44 of the CRPD and Article 12 of its Optional Protocol the European Union may act on behalf of its members in relation to the treaties to the extent of its mandate, which must be the subject of a formal declaration, deposited with the Secretary-General. While the European Union may also ratify the treaties, only the direct ratifications of its member States count towards the treaties coming into force. As far as the history and the process of the European ratification of the CRPD, see Waddington (2009).

${ }^{18}$ European Commission (1996) Communication of the Commission on equality of opportunity for people with disabilities: A new European Community disability strategy, COM(96) 406 final, 30 July 1996.
} 
principle of non-discrimination on the grounds of disability in primary legislation. Specifically including disability in the general non-discrimination Article 13, the Treaty expressly gave the European Community competence in the disability field for the first time. The non-discrimination approach in the field of disability was further embedded by Council Directive 2000/78/EC establishing a general framework for equal treatment in employment and occupation (Employment Equality Directive). It sets out broad equality and non-discrimination objectives-specifically including disability - in the field of employment and, crucially, calls on Member States to 'put into effect' the principle of equal treatment. Disability rights protection was strengthened when the Charter of Fundamental Rights of the European Union (hereinafter 'the Charter'), became legally binding with the adoption of the Lisbon Treaty in December 2009. Albeit limited to the areas of EU competence, the EU Charter of Fundamental Rights went beyond the Amsterdam Treaty in inserting Article 26 on the integration of persons with disabilities, reflecting core social model values of inclusion and equal opportunity, Article 21 by introducing a general prohibition of discrimination (explicitly mentioning the disability as one of the grounds of discriminations) and Article 15 on the protection of the freedom to choose an occupation and right to engage in work. ${ }^{19}$ The Charter also protects ancillary rights, such as the worker's right to information (Article 27), the right of collective bargaining (Article 28), the right of access to placement services (Article 29), the right to protection in the event of unjustified dismissal and the right to just and favourable working conditions (Article 30). All such rights, obviously, do apply to persons with disability.

As far as the compatibility with EU State aid rules, the General Block Exemption Regulation (GBER) exempts from notification obligations aid for the recruitment of disadvantaged workers and aid for the employment of disabled workers totalling, respectively, up to EUR 5 million and EUR 10 million per undertaking per year. ${ }^{20}$ The GBER covers aid for additional costs of employing disabled workers, such as the costs of adapting premises and equipment to disabled workers' needs and the costs of employing staff to assist disabled workers (Article 42). Aid in the form of wage subsidies for employing disabled workers may cover up to $75 \%$ of the wage costs and aid for up to $100 \%$ of eligible additional costs of employing disabled workers. For the purposes of the GBER, a 'disabled worker' is defined as a person who has 'a recognised limitation which results from physical, mental or psychological impairment' or is recognised as a disabled worker by national law (Article 2(20)). The GBER may apply to support for the habilitation and

\footnotetext{
${ }^{19}$ Article 15 of the European Charter on Fundamental Rights recognizes that everyone has the right to engage in work and to pursue a freely chosen accepted occupation; states that every citizen of the Union has the freedom to seek employment, to work, to exercise the right of establishment and to provide services in any Member State; and by entitles nationals of third countries, who are authorised to work in the territories of the Member States, to working conditions equivalent to those of citizens of the Union.

${ }^{20}$ Commission Regulation (EC) No 800/2008 of 6 August 2008 declaring certain categories of aid compatible with the common market in application of Articles 87 and 88 of the Treaty (General block exemption Regulation), Articles 40 and 41.
} 
rehabilitation of workers with disabilities, where such support constitutes State aid. In 2012, with its Communication on State aid Modernisation (SAM), the Commission launched a broad review of State aid rules. State aid enforcement should facilitate sustainable, smart and inclusive growth, focus on cases with the biggest impact on the single market, streamline the rules and provide for faster, better informed and more robust decisions. The reviewing process of the GBER has been completed in 2014 and the new GERB mechanism puts forward new ways of supporting the training and employment of workers with disabilities through the inclusion of new categories of eligible cost. It applies the term 'worker with disabilities' and adapts its definition to that in the CRPD. ${ }^{21}$

Lastly, another way in which Member States are permitted by EU law to favour disabled workers is through the use of disability considerations in public procurement processes. The revised public procurement Directives, adopted in $2014^{22}$ and replacing pre-existing legislation have broadened the possibility to reserve public contracts to certain economic operators. This will concern not only sheltered workshops, but also economic operators whose main aim is the social and professional integration of disabled or disadvantaged persons.

\subsection{The 2000/78/EC Employment Equality Directive}

Within the European legislation, specific legal discipline is provided by Council Directive 2000/78/EC (the so-called 'Employment Equality Directive'); the Directive requires Member States to prohibit, inter alia, discrimination on the grounds of disability in the fields of employment, occupation and vocational training. According to the Directive, Member States are required to prohibit direct discrimination, indirect discrimination, ${ }^{23}$ harassment, victimisation and instructions to discriminate on the grounds, inter alia, of disability.

\footnotetext{
${ }^{21}$ Commission Regulation (EU) No 651/2014 of 17 June 2014 declaring certain categories of aid compatible with the internal market in application of Articles 107 and 108 of the Treaty, see point (54) of the Preamble.

${ }^{22}$ Directive 2014/24/EU of the European Parliament and of the Council of 26 February 2014 on public procurement and repealing Directive 2004/18/EC; Directive 2014/25/EU of the European Parliament and of the Council of 26 February 2014 on procurement by entities operating in the water, energy, transport and postal services sectors and repealing Directive 2004/17/EC.

${ }^{23}$ Direct discrimination is considered to occur where one person is treated less favourably than another is, has been or would be treated in a comparable situation. Indirect discrimination is considered to occur where an apparently neutral provision, criterion or practice would put persons with a particular religion or belief, a particular disability, a particular age, or a particular sexual orientation at a particular disadvantage as compared with other persons, unless: (1) that provision, criterion or practice is objectively justified by a legitimate aim and the means of achieving that aim are appropriate and necessary; or (2) the employer, or any person or organisation to whom the Directive applies, is obliged under national legislation to take appropriate measures in line with the principles of 'reasonable accommodation for disabled persons' in order to eliminate disadvantages entailed by such provision, criterion or practice.
} 
As far as the CRPD 'reasonable accommodation' principle is concerned, Article 5 of the Directive deals with its implementation at EU level and requires that 'reasonable accommodation' be provided to guarantee compliance with the principle of equal treatment in relation to persons with disabilities. This means that employers and providers of vocational training must take appropriate measures, where needed in a particular case, to enable a person with a disability to have access to, participate in, or advance in employment, or to undergo training, unless such measures would impose a disproportionate burden on the employer. This burden is not regarded as disproportionate when it is sufficiently remedied by existing measures under the disability policy of the Member State concerned. ${ }^{24}$ The duty of employers to adjust reasonable accommodation for disabled people is a key element of protection of persons with disabilities under the Directive. Employers must provide reasonable accommodation to enable a person with a disability to have access to employment and advance in it; however, Member States may decide whether to make exceptions as regards disability and age when it comes to employment in the armed forces: the EU reservation on Article $27 \mathrm{CRPD}^{25}$ follows the logic of Article 3(4) of the Directive. ${ }^{26}$

The Commission has rigorously monitored the correct transposition of the Directive in national laws ${ }^{27}$ and initiated several infringement procedures against Member States for incorrect implementation. Indeed, it is the Commission's role to scrutinise whether a complaint reveals incorrect transposition or application of the

\footnotetext{
${ }^{24}$ From this perspective, the preamble to the Directive states that appropriate measures should be provided to adapt the workplace to the disability, for example by adapting premises and equipment, patterns of working time, the distribution of tasks or the provision of training or integration resources. The preamble also states that, to determine whether the measures in question give rise to a disproportionate burden, account should be taken in particular of the financial and other costs entailed, the scale and financial resources of the organisation or undertaking and the possibility of obtaining public funding or any other assistance. As for instance, EU health and safety legislation has been used as a means of requiring adaptations of the work environment for employees with disabilities. Thus, the 1989 Safety and Health Directive requires that workplaces are organised to take account of disabled workers, if necessary, in particular as regards doors, passageways, staircases, washbasins, lavatories and workstations used or occupied directly by handicapped persons.

${ }^{25}$ See Council Decision 2010/48/EC concerning the conclusion, by the European Community (now European Union), of the United Nations Convention on the Rights of Persons with Disabilities, containing in Annex III a reservation with respect to Article 27(1) of the CRPD, O.J. L 23/35 (2010).

${ }^{26} \mathrm{See}$, as for instance, the UK's reservation to the Directive in respect of service in the Armed Forces. Service in the Armed Forces was exempt from the employment provisions of the Disability Discrimination Act (DDA) 1995, on grounds that Armed Forces personnel must be combat effective in order to meet a worldwide need to deploy, and to ensure that military health and fitness remain matters for Ministry of Defence Ministers based on military advice, not the courts. The continuing need for this exemption was reviewed when the Equality Act 2010 was developed, and it was concluded that it is still required. The reservation reflects this position.

${ }^{27}$ National provisions communicated by the Member States concerning Council Directive 2000/ 78/EC are available at: http://eur-lex.europa.eu/legal-content/EN/TXT/?qid=1401876783757\& uri $=$ CELEX:32000L0078.
} 
Directives by the Member State concerned. At the moment, two non-conformity infringements case ${ }^{28}$ and three complaint-based cases under Directive 2000/78/EC are currently pending. ${ }^{29}$ In 2014 the Commission published a report on the implementation of the Directive according to which, while all Member States have transposed EU rules in national law, further efforts are needed to apply them in practice, in particular through policy action, awareness-raising and training. ${ }^{30}$

\title{
3.3 The Notion of 'Disability' of the Directive and ASD: The Judicial Enlargement Performed by the Case-Law of the CJEU and Its Effects on National Laws
}

\begin{abstract}
Differently than Article 1 of the CRPD, the Directive does not define disability and therefore does not clarify which groups of persons are protected from discrimination. In particular, it does not expressly indicate whether persons with ASD are included. Indeed, it appears from the research's findings that there is still a lack of clarity in European national legislations regarding the definition of disability and in particular whether it includes persons with ASD. ${ }^{31}$ In the majority of countries, the legislation transposing the Employment Equality Directive either does not define the term disability or provides language open to interpretation as to its exact scope of application. This highlights the importance of interpretation when applying such legislation and its capacity to confirm that the scope of protection extends to persons with ASD. There is thus the risk that narrower interpretations of the concept of disability in national legislation and in judicial case law may limit the scope of the protection offered by the Directive excluding certain groups, notably persons with social interaction, communication, and understanding impairments (this risk, therefore, main involve persons with ASD). ${ }^{32}$
\end{abstract}

\footnotetext{
${ }^{28}$ Non-conformity infringement cases concern Belgium and Romania.

${ }^{29}$ Two cases concern Greece and discriminatory age limits in public service, one case concerns the Czech Republic and insufficient protection from discrimination for disabled persons seeking employment.

${ }^{30}$ See Report from the Commission to the European Parliament and the Council, Joint Report on the application of Council Directive 2000/43/EC of 29 June 2000 implementing the principle of equal treatment between persons irrespective of racial or ethnic origin ('Racial Equality Directive') and of Council Directive 2000/78/EC of 27 November 2000 establishing a general framework for equal treatment in employment and occupation ('Employment Equality Directive'), COM (2014) 2 final, 17 January 2014 available at the following website http://ec.europa.eu/justice/ discrimination/files/com_2014_2_en.pdf.

${ }^{31}$ On this aspect see the chapter by V. Della Fina, in this volume.

${ }^{32}$ As for instance, Denmark legislation uses the term 'handicap'. A person with a handicap is described in the 2008 Civil Act no. 1349 on the Prohibition of Discrimination in the Labour Market a person with a 'physical, psychological or intellectual impairment who must be compensated in order for that person to function on an equal level with other citizens in a similar situation.' Whether this definition of disability is broad enough to live up to Danish obligations under the
} 
The CJEU case law has filled this gap by giving some landmark rulings on the ground of disability.

In the first place, in the 2006 case Chacon Navas v. Eurest Collectividades SA, the Court by ruling that the concept of 'disability' 'should be given an autonomous and uniform interpretation', made a distinction between 'sickness' and 'disability' and concluded that whereas the latter is protected by the Directive the former is not automatically afforded protection.

In second place, in 2008, in the Coleman v. Attridge Law and Steve Law judgement, ${ }^{33}$ the ECJ Court has enlarged the scope of application ratione personae of the Directive by stating that it includes also the protection against situations of 'discrimination by association' protecting victims of discrimination who do not themselves have a disability. According to the Court of Justice point of view, Directive 2000/78/EC protected a mother of a disabled child from harassment and discrimination in employment, when the problems were due to the fact that the mother needed extra time off to take care of her child.

Finally, in 2013 decision in the case HK Danmark ${ }^{34}$ the Court, while admitting that the concept of disability can in certain circumstances also include conditions caused by incurable or curable long-term illnesses, ruled that disability '. . .results in particular from physical, mental or psychological impairments which in interaction with barriers may hinder the full and effective participation of the person concerned in professional life on an equal basis with other workers, and the limitation is a long term one... ${ }^{35}$ In sum, with such decisions the Court has upheld the position of the Advocate General Geelhoed who, in his Opinion on the case Chacon Navas concluded that the concept of disability 'must be interpreted autonomously and uniformly throughout the Community legal system ${ }^{36}$ but acknowledged the difficulties in finding a definition, as the concept of disability is 'undergoing fairly rapid evolution' and may be interpreted differently in different contexts. ${ }^{37}$ He argued, therefore, that we should not endeavour to find more or less exhaustive and fixed definitions of the term 'disability', 38 and made a proposal that has inspired the Court in the HK Danmark judgment. At para 37 of the HK Danmark

\footnotetext{
Employment Equality Directive and to include ASD is matter of big controversy: in 2012 a case concerning a child-minder who claimed to be discriminated against on grounds of the disability of her son, who suffered from Asperger's syndrome, was held before the Danish Equal Treatment Board who concluded that any possible impairments suffered by the complainant's son in the long run could not be deemed with sufficient certainty to constitute disability within the meaning of the Anti-discrimination Act. In other words, according to the Board, ASD did not constitute a disability and the complainant had not therefore faced discrimination because of her son's disability (see Decision No. 275/2012 of 9 May 2012).

${ }^{33}$ See Coleman v. Attridge Law and Steve Law, Case C-303/06, judgment of 17 July 2008.

${ }^{34}$ See, joined Cases C-335/11 and C-337/11, HK Danmark, judgment of 11 April 2013.

${ }^{35}$ Ibid., para 1 of the grounds of the decision.

${ }^{36}$ Opinion of Advocate General Geelhoed, ECJ, C-13/05, Chacón Navas v. Eurest Colectividades SA, 16 March 2006, para 64.

${ }^{37}$ Ibid., para 58.

${ }^{38}$ Ibid., para 67.
} 
judgment, in effect, the Court noted how, after the judgment in Chacón Navas had been delivered, the European framework in this field changed due to the entry into force of the CRPD for the European Union. ${ }^{39}$ Consequently, the European Union is bound by the Convention within the limits of its competences ${ }^{40}$ and Directive 2000/ 78/EC must, as far as possible, be interpreted in a manner consistent with the Convention and with its principles. ${ }^{41}$ Among these principles the Court noted how the CRPD acknowledges in recital (e) that 'disability is an evolving concept and that disability results from the interaction between persons with impairments and attitudinal and environmental barriers that hinders their full and effective participation in society on an equal basis with others'; the Court went on noting also that in the second paragraph of Article 1 the CRPD states that persons with disabilities include 'those who have long-term physical, mental, intellectual or sensory impairments which in interaction with various barriers may hinder their full and effective participation in society on an equal basis with others'.

At the end of the game, the extensive approach adopted by the CJEU has allowed the same Court to interpret discrimination on the grounds of disability in line with the spirit of the CRPD. The notion of disability developed by ECJ case law include three cumulative requirements: there must be a limitation which results in particular from physical, mental or psychological impairments; the limitation must hinder the participation of the person concerned in professional life; and it must be probable that the limitation will last for a long time.

ASD is consistent with this three-tiered test ${ }^{42}$; therefore ASD fall within the scope of application of the EU legislation in this field area. At the end of the game, persons with ASD may receive protection under member States' domestic legislation transposing the Directive, in two ways. In the first place, States may enact legislation, or amend already existing legislation, by which ASD is expressly included in the domestic legislative notion of disability. ${ }^{43}$ In the second place,

\footnotetext{
${ }^{39}$ The European Union signed the Convention on 30 March 2007 and the Convention entered into force with respect to the EU on 22 January 2011. The CRPD is the first legally binding international human rights instrument to which the European Union has become a party. EU's first periodic report on the implementation of the UN Convention on the Rights of Persons with Disabilities has been delivered in June 2014.

${ }^{40}$ These are illustrated in Annex II to Council Decision 2010/48/EC of 26 November 2009 concerning the conclusion, by the European Community, of the United Nations Convention on the Rights of Persons with Disabilities, OJ L 23 of 27.1.2010, p. 35.

${ }^{41}$ See paras $28-37$ of HK Danmark judgment.

${ }^{42}$ As far as international accepted medical standards encompassing ASD see WHO's International Classification of Diseases and Related Health Problems, which concerns Mental and Behavioural Disorders (ICD-10), disposable online at the following site www.apps.who.int/classifications/ icd10/browse/2010/en.

${ }^{43}$ As for example, in Ireland Section 1 of the 2012 Autism Bill amended the definition of disability in the Employment Equality Act 1998 to include reference to autism; Section 2 introduced similar provision in the Equal Status Act 2000. Similarly, North Ireland the Autism Act 2011 amended Schedule 1 to the Disability Discrimination Act 1995 (c. 50) with the same objective. England Autism Act 2009 enacted similar provisions with the aim that 'definitional issues will be dealt with
} 
absent an explicit inclusion of ASD within legislative notion of disability, its up to the domestic courts, through their judicial interpretation activity, to render domestic law consistent with Directive's and international standards by enlarging the scope ratione personae of domestic provisions on disability to persons with ASD. Lacking an action by domestic courts it is up to supra-national bodies of control (i.e. the CJEU in this case) to assure the full and correct transposition of the European principles. ${ }^{44}$

\subsubsection{Article 5 of the Directive and the Duty to Provide Reasonable Accommodation in the Field of the Employment}

Provision of reasonable accommodation for disabled persons by the employer is one of the key elements of the Directive and the Commission has rigorously monitored its correct transposition in national laws. ${ }^{45}$ In effect, Member States use different terminology to refer to the term 'accommodation' as set forth in the Employment Equality Directive. While many Member States chose to use the terminology of the Directive, others have replaced the word 'accommodation' with alternative terms such as 'adjustments', 'steps' or 'measures'. ${ }^{46}$ Furthermore, the comparative analysis of the national legislation transposing the Directive further reveals that the meaning of the term 'reasonable' has been interpreted by Member States in two different ways. While some Member States have interpreted the term 'reasonable' to refer to an accommodation which does not result in excessive costs,

in the autism strategy, which, as it has to be kept under continual review, will allow for changes to be made much more quickly in response to new developments than if the definition were to be included in primary legislation' (see commentary to Section 1 of the 2009 Autism Act). In other situations States enact domestic legislation, which, without making reference to the ASD, apply a wide-ranging notion of disability that is consistent with benchmarks fixed in the CRPD. As for instance, new Croatian Social Care Act of 2012 defines a person with a disability as a person with long-term physical, mental, intellectual or sensory impairments that, in interaction with various barriers, may hinder her full and effective participation in society on an equal basis with persons without disabilities.

${ }^{44}$ This is what happened as far as the already cited $H K$ Danmark case before the CJEU. The definition of disability provided with the Denmark Act on the Prohibition against Discrimination in the Labour Market, was excessively narrow and was not in line with Denmark's obligations under the Directive.

${ }^{45}$ Article 5 of the Directive includes a duty to provide reasonable accommodation for persons with disabilities. It requires employers, in certain cases, to take appropriate measures to enable persons with disabilities to have access to, participate in, or advance in employment, or to undergo training, unless such measures would impose a disproportionate burden on the employer.

${ }^{46}$ In the United Kingdom the domestic legislation requires the making of reasonable "adjustments"; Finnish law refers to "steps"; the Irish Employment Equality Act 1998-2004 and the French Labour Code, drawing their inspiration from Recital 20 to the Directive, define a reasonable accommodation as an "appropriate measure"; this term is also found in the Lithuanian Law on Equal Treatment of 2005 and the Slovakian Act on Equal Treatment in Certain Areas and Protection Against Discrimination of 2004. 
difficulties or problems for the employer, ${ }^{47}$ others have associated the term 'reasonable' to the quality of the accommodation, meaning that the accommodation must be effective in terms of allowing an individual with a disability to carry out a particular set of employment-related tasks. ${ }^{48}$

However, a number of Member States initially had problems in respect to the implementation of Article 5 of the Directive and were addressees of infringement procedures. $^{49}$

In the great majority of EU Member States, non-discrimination legislation contains a duty to provide reasonable accommodation for persons with disabilities. As for instance, the Estonian Equal Treatment Act, transposing the Employment Equality Directive, requires employers to 'take appropriate measures, where needed in a particular case, to enable a person with a disability to have access to, participate in, or advance in employment, or to undergo training, unless such measures would impose a disproportionate burden on the employer'. ${ }^{50}$ Similar provisions, as part of the transposing legislation, may be found, for example, in Finland, ${ }^{51}$ Poland, ${ }^{52}$ Spain, ${ }^{53}$ Sweden ${ }^{54}$ and the United Kingdom. ${ }^{55}$ From this side, it may be argued that in a majority of countries, the scope of the transposing legislation that provides for reasonable accommodation can be interpreted to include persons with ASD. However, in some Member States, even though the transposing legislation provides for reasonable accommodation it does not contain a definition of disability, which

\footnotetext{
${ }^{47}$ This approach has been incorporated, as for instance, in the Finnish Non-Discrimination Act $21 / 2004$, which obliges employers and trainers to 'take any reasonable steps to help a person with disabilities to gain access to work or training, to cope at work and to advance their career.' According to the Act 'In assessing what constitutes reasonable [sic], particular attention shall be devoted to the costs of the steps, the financial position of the person commissioning the work or arranging the training, and the possibility of support from public funds or elsewhere towards the costs involved'.

${ }^{48}$ A leading example of a jurisdiction which has transposed Article 5 of the Directive in this way is the Netherlands. The Dutch Act on Equal Treatment on Grounds of Disability or Chronic Illness 2004 provides that the prohibition of making distinction '[ . . ] also includes the duty for the person to whom the prohibition is addressed, to make effective accommodations in accordance to the need for this, unless doing so would constitute a disproportionate burden upon her.' The Dutch statute, therefore, does not require a "reasonable accommodation", but instead establishes a duty to make 'effective accommodations.'

${ }^{49}$ Belgium, Estonia, Cyprus, Italy, Latvia, Lithuania, Hungary, Poland and Slovakia. Some Member States had been criticised for interpreting the Directive as limiting the duty of reasonable accommodation to existing workers, thus wrongly excluding both applicants and trainees. The majority of infringement procedures have been closed by now.

${ }^{50}$ Estonia, Law No. 315 of 11 December 2008 on Equal Treatment, para 11.

${ }^{51}$ See Section 5 of the Finnish Non-discrimination Act 21/2004 and its successive amendments.

${ }^{52}$ See the 1997 Act on Vocational and Social Rehabilitation and Employment of Persons with Disabilities, Article 23a.

${ }^{53}$ See Law 51/2003 on Equal Opportunities, Non-Discrimination and Universal Access for Persons with Disabilities, Article 7.

${ }^{54}$ See the 2008 Discrimination Act, Chapter 2, Section 1.

${ }^{55}$ See 2010 Equality Act, Section 20.
} 
makes assessing whether the duty to provide reasonable accommodation also applies to persons with ASD rather difficult. Only a judicial or quasi-judicial decision could clarify the situation. For example, in Greece, Article 10 of the transposing legislation closely follows the wording of the Employment Equality Directive, but as Law No. 3304/2005 does not provide any definition of disability, and there is, to date, no national case-law to provide guidance, it is unclear whether persons with ASD could benefit from the reasonable accommodation provision.

This situation may be perceived also in other EU countries in which the scope of the duty to provide reasonable accommodation is not the same as the scope of the prohibition of discrimination on the grounds of disability. For instance, in France, the obligation to provide reasonable accommodation is subject to an additional requirement to those laid down in the definition of disability under Article L 114 of the Social Policy and Family Code. Articles L 5212-13 and L 5213-6 of the Labour Code use a different and more limited definition of disability which stipulates that only individuals who are officially recognised as disabled can claim an accommodation. Therefore, 'non-registered' disabled people, along with all others not falling within the requirements laid down in Article L 5212-13 of the Labour Code, are not covered by the obligation of reasonable accommodation.

In Germany, the General Treatment Act, which transposes the directive, refers to the definition if disability in Article 2(1) of the Social Code Book. However, the duty to provide reasonable accommodation, according to Article 81(4) and (5) of the Social Code Book IX, applies to persons with a severe disability, defined in Article 2(3) of the Social Code Book IX as persons with a degree of disability of more than $50 \%$, or between 30 and $50 \%$, if they would be unable without equal rights provisions to find or keep suitable employment.

Persons with ASD may therefore only benefit from reasonable accommodation provisions insofar as they have a degree of disability of at least $30 \%$. The European Commission initiated infringement proceedings against Germany for incorrectly implementing its obligation to include regulations on reasonable accommodation under Article 5 of the Employment Equality Directive. Legal proceedings were closed in October 2010, after Germany presented draft laws implementing national case law which secured compliance with the Directive's requirements.

One Member State (Italy) has been found to be in breach of the Directive by the CJEU on 4 July 2013 due to failure to correctly transpose the provision by not comprehensively covering all disabled persons. Indeed, while Legislative Decree No. 216/2003, which transposed the Employment Equality Directive, did not contain a reasonable accommodation clause, the national authorities argued that reasonable accommodation was provided for by measures in other pieces of legislation, such as Law No. 104/1992 and Law No. 68/1999. However, on 6 April 2011, the European Commission referred Italy to the Court of Justice of the European Union pointing out that Italy had not completely transposed Article 5 of the Employment Equality Directive. The European Commission considered that Italian law did not provide for a general rule of reasonable accommodation for persons with disabilities in all aspects of employment. On 4 July 2013 the Luxemburg Court upheld the position of the Commission and condemned Italy which has been 
obliged to amend its own legislation. ${ }^{56}$ Quite all the remaining infringement procedures have been closed by now.

\subsubsection{The Gaps of the Directive as to the Notion of 'Reasonable Accommodation'}

The Directive does not further define the concept of reasonable accommodation; in particular, it does not state, while CRPD does, whether denial of reasonable accommodation is a form of discrimination. Nevertheless, some guidance as to the meaning of the 'appropriate measures', which are required under the duty to provide reasonable accommodation is provided in Recital 20 of the Preamble, while Recital 21 elaborates on the concept of 'disproportionate burden'.

National laws, however, should define closely what is meant by reasonable accommodation, so that misinterpretation is avoided and employers clearly understand what they must do. As for example, in the United States, the obligation to make a reasonable accommodation is to be found in the Americans with Disabilities Act 1990. Reasonable accommodation, hence, is understood to mean any change in the work environment or in the way a job is performed that enables a person with a disability to enjoy equal employment opportunities. There are three categories of reasonable accommodations: changes to a job application process, changes to the work environment or the way a job is usually done, and changes that enable an employee with a disability to enjoy equal benefits and privileges of employment, such as access to training. Furthermore, in other countries, including Australia, ${ }^{57}$ New Zealand ${ }^{58}$ and South Africa ${ }^{59}$ legal provisions stipulating that the failure to provide a reasonable accommodation constitutes a form of discrimination there exist. This is consistent with provisions of the CRPD which stipulates that this failure be considered as a form of discrimination.

However, even in this circumstance the CJEU case law has played a vanguard role enlarging the scope of the protection afforded by the Directive. In its first decisions on the implementation of the Directive, indeed, the CJEU has also clarified what the notion of 'reasonable accommodation' has to be meant in the light of the CRPD standards. Under a first perspective in the 2013 Commission v. Italy case (C-312/11, decision 4 July 2013), the Court has clarified that mere support and incentives measures are not sufficient for assuring the fair and effective transposition of the directive; according to the Court, indeed:

\footnotetext{
${ }^{56}$ See Article 9, 4ter, of the Law decree no. 76/2013, converted in Law 99/2013, which has added the Article 3 bis into the law of transposition of Equal employment Directive (i.e. Legislative Decree 216/2003). The normative amendment is currently under examination by the Commission.

${ }^{57}$ See Australia's Disability Discrimination Act of 1992.

${ }^{58}$ See Human Rights Act of 1993.

${ }^{59}$ See Employment Equity Act No. 55 of 1998.
} 


\begin{abstract}
il ne suffit pas, pour transposer correctement et pleinement l'article 5 de la directive 2000/ 78, d'édicter des mesures publiques d'incitation et d'aide, mais il incombe aux États membres d'imposer à tous les employeurs l'obligation de prendre des mesures efficaces et pratiques, en fonction des besoins dans des situations concrètes, en faveur de toutes les personnes handicapées, portant sur les différents aspects de l'emploi et du travail et permettant à ces personnes d'accéder à un emploi, de l'exercer ou d'y progresser, ou pour qu'une formation leur soit dispensée.
\end{abstract}

Under a second perspective, i.e. which are the appropriate measures that the employer is required to take in order to enable a person with a disability to have access to, participate in, or advance in employment, in the HK Danmark Judgment, the Court has underpinned, and despite the contrary opinion of the national employers, that as recital 20 in the preamble to Directive 2000/78 and the second paragraph of Article 2 of the CRPD envisage 'not only material but also organisational measures, and the term 'pattern' of working time must be understood as the rhythm or speed at which the work is done, it cannot be ruled out that a reduction in working hours may constitute one of the accommodation measures referred to in Article 5 of that Directive' (para 55).

\title{
3.4 The Council of Europe Standards on Reasonable Accommodation
}

Council of Europe standards do not make reference to the terminology 'reasonable accommodation' as such, instead using the term 'reasonable adjustment'. Article 15 (2) of the European Social Charter (revised) calls on Parties to 'adjust the working conditions to the needs of the disabled' and Article 15(3) urges them to promote social integration and participation in the life of the community 'through measures, including technical aids, aiming to overcome barriers to communication and mobility and enabling access to transport, housing, cultural activities and leisure'. Case law delivered on this issue by the European Committee on Social Rights has confirmed the duty of States to provide reasonable accommodation under Article 15(2) of the revised Charter and has also concluded in several occasions for nonconformity with this provision ${ }^{60}$ demonstrating to considering the duty of reasonable accommodation as a crucial requirement in non-discrimination legislation in the area of disability. As for instance, in its 2003 Conclusions on France, the Committee specifically asked France to provide further information 'on how the concept of reasonable accommodation is incorporated in the legislation'. ${ }^{61}$

\footnotetext{
${ }^{60}$ See Council of Europe, European Committee of Social Rights, Conclusions (2008)—Articles $1,9,10,15,18,20,24,25$, Armenia p. 58, Belgium p. 131, Cyprus pp. 201-204; available at www. coe.int/t/dghl/monitoring/socialcharter/Conclusions/ConclusionsYear_en.asp.

${ }^{61}$ See Council of Europe, European Committee of Social Rights, Conclusions (2003) France, p. 68, available at: www.coe.int/t/dghl/monitoring/socialcharter/Conclusions/State/France2003_ en.pdf.
} 
As far as the European Convention on human rights, the ECtHR case law has also reinforced member States' duty to provide reasonable accommodation, and by adopting a wide approach to its interpretative activity has derived the duty to accommodate from some provisions of the Convention in some cases. In the case of Glor v. Switzerland, where the Court found a violation of Article 14 in conjunction with Article 8 of the ECHR, it suggested that people in the applicant's situation might be offered the possibility of alternative forms of service in the armed forces that entailed less physical effort and were compatible with the constraints of a partial disability. Moreover, for the first time the Court's judgment makes explicit reference to the CRPD as an example of the existing European and universal consensus on the need to protect persons with disabilities from discriminatory treatment. $^{62}$

Turning to the CoE Committee of Ministers, the Recommendation No. Rec (2006)5 containing the Action Plan to promote the rights and full participation of people with disabilities in society: improving the quality of life of people with disabilities in Europe 2006-2015 (hereinafter the Action Plan) ${ }^{63}$ refers to the need for 'reasonable adjustments' in order to achieve the objective of full participation of persons with disabilities. More in particular, Action line No. 5 on employment, vocational guidance and training asks Member States to make reasonable adjustments. States must 'ensure that people with disabilities have access to vocational guidance, training and employment-related services at the highest possible qualification level, and making reasonable adjustments where necessary'. ${ }^{64}$ States must also encourage employers to employ people with disabilities by, for example, 'making reasonable adjustments to the workplace or working conditions, including telecommuting, part-time work and work from home, in order to accommodate the special requirements of employees with disabilities'. ${ }^{65}$

\footnotetext{
${ }^{62}$ See, Glor v. Switzerland, application No. 13444/04, judgment of 30 April 2009, para 53.

${ }^{63}$ Council of Europe, Committee of Ministers (2006) Recommendation Rec(2006) on the Council of Europe Action Plan to promote the rights and full participation of people with disabilities in society: improving the quality of life of people with disabilities in Europe 2006-2015, 5 April 2006.

${ }^{64}$ Ibid. section 3.5.3, iii.

${ }^{65}$ Ibid. section 3.5.3, v.
} 


\section{The Impact of the Financial and Economic Crisis on the Implementation of Art 27 Rights and the Progressive Realization of Economic, Social and Cultural Rights}

Some final remarks are required as to the relationships amongst the State duty to assure the right to employment of persons with ASD, the contemporary economic crisis and the principle of progressive realization of rights in the field of ESC rights. Indeed, the full implementation of Article 27 rights requires that adequate resources be allocated to this goal by States. However, the available resources may be increasingly limited, and the resource allocation undermined, by the contemporary financial crisis and economic recession, as well as by anti-crisis measures to be adopted by States for the alleviation of their debt and debt-service burdens. Such measures, in fact, usually apply structural adjustment policies aimed at curbing public expenditures for social welfare, or involve measures of privatization of the economy and, consequently, oblige States to re-allocate resources with the view of ensuring strict compliance with the commitments derived from international agreements on foreign debt. This occurs even at the cost of reducing the allocation of resources for realizing other international obligations, such as those prescribed by international human rights and, especially, by economic, social and cultural rights.

In sum, States might pretend that as every other ESC rights, the full realization of right to employment of persons with ASD too should be subject to progressive realization and, therefore, be implemented only within the extent permitted by available resources. Realization of this right could be hampered by a lack of resources and be achieved only over a period of time. States, in the second place, might pretend to be legitimized to derogate from respecting their duties in the field of the employment of persons with disabilities in response to the exceptional and emergence situations such as the global financial crisis and to the debt restructuring mechanisms. ${ }^{66}$ As far as the first aspect, there are some duties deriving from Article 27 CRPD which States may not derogate. Indeed, even if the principle of

\footnotetext{
${ }^{66}$ This situation is perfectly illustrated, mutatis mutandis, by the review before the European Committee of Social Rights of the Greek national measures adopted to redress the effects of economic crisis in the recent GENOP-DEI and ADEDY v. Greece cases (see ESC/C, Complaint No. 65/2011, General Federation of Employees of the National Electric Power Corporation (GENOP-DEI) and Confederation of Greek Civil Servants' Trade Unions (ADEDY) v. Greece, 23 May 2012, para 17; and ESC/C, Complaint No. 66/2011, General Federation of Employees of the National Electric Power Corporation (GENOP-DEI) and Confederation of Greek Civil Servants' Trade Unions (ADEDY) v. Greece, 23 May 2012, para 13). The government in both cases has made some preliminary statements aimed at underpinning the fact that challenged measures were 'part of an overall package of initiatives adopted as a response to this crisis'. Such observations, albeit without mentioning Articles G and F of the Revised European Social Charter, seem to constitute an attempt to justify any eventual impact that the adoption of these measures might have had on the rights guaranteed by the Charter, with the exceptional economic and financial situation that Greece has to face.
} 
progressive realization describes a pivotal aspect of States' obligations in connection with economic, social and cultural rights under international human rights treaties, and even if this principle is well-established in these treaties, included the CRPD's Article $4,{ }^{67}$ the CRPD Committee has recently clarified in its Concluding Observations on Spain that 'the duty to provide reasonable accommodation is immediately applicable and not subject to progressive realisation ${ }^{68}{ }^{68}$ From this perspective it might be argued that the duty to provide reasonable accommodation may be seen as a kind of 'minimum core obligation' under CRPD. As far as the second aspect, who is writing has already demonstrated ${ }^{69}$ that even in situations of financial crisis and recession-perhaps, especially in such situations-States are not completely boundless with regard to economic, social and cultural rights because these rights may not be considered to be at States' complete discretion. On the contrary, even in these dramatic circumstances, States are requested not to distribute the burden of the rigour unequally among social groups, omitting to afford protection to vulnerable and disadvantaged groups that make up the at-risk categories during such circumstances. Furthermore they bear the immediate due diligence duty to strike a fair balance between obligations arising from their external debt objectives, for example, the implementation of austerity measures for consolidating public spending, and the obligations enshrined in international human rights law: in these circumstances, striking the fair balance requires that austerity measures be enforced by avoiding any discrimination amongst individuals or amongst groups of individuals and be consistent with the principles of reasonableness and proportionality. This applies also to the enforcement of the principle of reasonable accommodation in the field of the employment of persons with disability or with ASD.

\section{Conclusions}

Individuating best practices as far as implementation of Article 27 CRPD and the degree of employment inclusion of persons with ASD is a hard task. Several requirements have to be assessed from this perspective: from the existence of an enabling legal environment, enhancing accessibility and addressing

\footnotetext{
${ }^{67}$ See CRPD Article 4: 'With regard to economic, social and cultural rights, each State Party undertakes to take measures to the maximum of its available resources and, where needed, within the framework of international cooperation, with a view to achieving progressively the full realization of these rights, without prejudice to those obligations contained in the present Convention that are immediately applicable according to international law'.

${ }^{68} \mathrm{UN}$, Committee on the Rights of Persons with Disabilities (2011b) Consideration of reports submitted by States parties under article 35 of the Convention: Concluding observations of the Committee on the Rights of Persons with Disabilities (Spain), CRPD/C/ESP/CO/1, 23 September 2011.

${ }^{69}$ See Fasciglione (2014) cit., pp. 42-45.
} 
misunderstandings concerning people with disabilities to the presence of vocational and skills training opportunities for persons with disabilities. Moreover, the level of protection of employment rights of autistic persons in each country depends by several factors including social, cultural and economic circumstances: these factors may change on the basis of countries concerned. From this perspective, according to our point of view, there is no a one size-fit-for-all approach in the normative implementation employment rights of persons with ASD, but different régimes may be enforced, on a case by case basis, with the aim of striving at maximum Article 27 rights.

However, what emerges from the analysis performed is the circumstance that disability-related legislations to be adopted at national level in this field area have to rely on two 'normative principles', at the very least. In the first place, the adoption of a normative definition of disability sufficiently wide in order to include ASD cases and, in the second place, the avoidance of national legislations ambiguous about whether failure to provide reasonable accommodation is to be treated as a form of unlawful discrimination. ${ }^{70}$ These two principles have to be regarded as benchmarks to be applied by national States in implementing legislations.

As far as the notion of disability the new Croatian Social Care Act of 2012 may be cited. The 2012 Act adopts the definition of disability provided by the UN CRPD and defines a person with a disability as a person with long-term physical, mental, intellectual or sensory impairments that, in interaction with various barriers, may hinder her full and effective participation in society on an equal basis with persons without disabilities: a definition that, as we have seen before, is sufficiently broad and may be interpreted as including also ASD.

Other countries have preferred to include explicitly ASD in normative definition of disability at national level, by adopting specific provisions in this sense. In Ireland, the 2012 Autism Bill aims to provide for an autism strategy to provide a coherent and national framework for addressing the specific needs of adults with ASD. Its Section 1 amends the definition of "disability" in the Employment Equality Act 1998 to include specific reference to autism. Section 2 makes similar provision in the Equal Status Act $2000 .{ }^{71}$ Similarly, in UK, who enacted in 2009 a specific legislation in the field of autism (the 2009 Autism Act), the Section 6 of the 2010 Equality Act provides with a wide-range definition of disability, consistent with the CRPD, as a physical or mental impairment which has a substantial and adverse long-term effect on the person' ability to carry out normal day-to-day activities. What is important to stress here is the circumstance that according to the 'Guidance on matters to be taken into account in determining questions relating

\footnotetext{
${ }^{70}$ This is the case, for instance, of the Hungarian See Act on the Rights of Persons with Disabilities and the Guaranteeing of their Equal Opportunities, and Latvian Labour Law.

${ }^{71}$ Moreover, Sect. 3 creates an obligation to produce an autism strategy. Section 4 sets out a duty to implement the strategy. On national autism plans and strategies see the chapter by V. Della Fina, in this volume.
} 
to the definition of disability' for the purposes of the 2010 Act the notion of 'impairments' have to be interpreted as including ASD. ${ }^{72}$

As far as the need for treating the failure to provide reasonable accommodation as a form of unlawful discrimination, in France, the failure to meet the duty constitutes unlawful discrimination, even if it is not specified whether this is classified as direct or indirect discrimination. ${ }^{73}$ In Sweden, on the contrary, failure to provide reasonable accommodation is treated as direct discrimination in the fields of employment and education, ${ }^{74}$ while failure to provide reasonable accommodation is treated as indirect discrimination in Austria and Denmark. ${ }^{75}$ Furthermore, in the United Kingdom failure to provide reasonable accommodation is defined as a specific form of discrimination ${ }^{76}$ and in the Netherlands as a prohibited form of distinction. ${ }^{77}$

Finally, other countries have chosen to adopt a broader approach to this issue. Interestingly, according to Slovakia law, failure to provide reasonable accommodation is regarded as a violation of the principle of equal treatment (which is broader than the prohibition of discrimination and its individual forms and also encompasses the duty to adopt measures to prevent discrimination) and it does not equate to direct or indirect discrimination. However, this does not mean that in specific situations the actions or omissions of an employer cannot at the same time also fall within definitions of the specific forms of discrimination defined by the Slovak Anti-discrimination Act: mainly direct or indirect discrimination or harassment. $^{78}$

\footnotetext{
${ }^{72}$ Equality Act 2010, Guidance on matters to be taken into account in determining questions relating to the definition of disability, on the 'Meaning of impairments' p. 9. UK courts hearing employment cases have had no problems in accepting that ASD and other common physical and psychological disorders are 'disabilities' under the Equality Act 2010: ASD (in Hewett v. Motorola, UKEAT/0526/03, Employment Appeal Tribunal, 2004) Personality disorder (in The Carphone Warehouse Ltd v Mr S Martin, UKEAT/0371/12/JOJ, and UKEAT/0372/12/ JOJ); Dyslexia (in Price v Transport for London, UKEAT/0005/11/JOJ); Mental impairment, personality disorder and major depression (in Jennings $v$ Barts and the London NHS Trust, [2013] Eq. L.R. 326); Multiple Sclerosis (in Burke v College of Law, [2012] EWCA Civ 37; Post traumatic stress disorder (in Abbey National Plc v Dutton, UKEAT/0879/04/CK).

${ }^{73}$ See the Labour Code, Articles L 5212-2, L5212-13 and L5213-6. Race or ethnic origin. And the Law No. 2005-102 on Disability, Article 24 IV and 32.

${ }^{74}$ See Discrimination Act, Chapter 2, Section 1.

${ }^{75}$ See the Austrian Employment of People with Disabilities Act, paras 7c (4)-(6) and the Federal Disability Equality Act, paras 6(3), 6(4). As far as Denmark see the Act on Prohibition of Discrimination in the Labour Market, Article 2(a).

${ }^{76}$ See the 2010 Equality Act, Section 20.

${ }^{77}$ See the Disability Discrimination Act, Article 2. In the Netherlands, the word 'distinction' is used in the equal treatment legislation, instead of 'discrimination'. Although the Government is taking the stance that there is no substantive difference between these words, this choice of terminology has engendered a lot of criticism.

${ }^{78}$ See the Slovakian Act on Equal Treatment in Certain Areas and Protection against Discrimination, Section 7.
} 
Open Access This chapter is distributed under the terms of the Creative Commons Attribution Noncommercial License, which permits any noncommercial use, distribution, and reproduction in any medium, provided the original author(s) and source are credited.

\section{References}

Fasciglione M (2014) The protection of economic, social and cultural rights of persons belonging to marginalized and vulnerable groups in times of financial crisis: how to reconcile the irreconcilable? Eur Yearb Minor Iss 11:1-47

Flynn E (2011) From rhetoric to action: implementing the UN Convention on the rights of persons with disabilities. Cambridge University Press, Cambridge

Hendricks A (2007) UN Convention on the rights of persons with disabilities. Eur J Health Law 14 (3):273-298

International Labour Organization (2004) Mauritius country profile. Employment of people with disabilities: the impact of legislation (East Africa). ILO, Geneva

Kayess R, French P (2008) Out of darkness into light? Introducing the Convention on the rights of persons with disabilities. Hum Rights Law Rev 8(1):1-34

Lawson A (2007) The United Nations Convention on the rights of persons with disabilities: new era or false dawn? Syracuse J Int Law Commer 34(2):563-618

Waddington L (2009) Breaking new ground: the implications of ratification of the UN Convention on the rights of persons with disabilities for the European Community. In: Arnardóttir OM, Quinn G (eds) The UN Convention on the rights of persons with disabilities: European and Scandinavian perspectives. Martinus Nijhoff Publisher, Leiden/Boston, pp 111-140

World Health Organization, The World Bank (2011) World report on disability. WHO, Geneva. http://whqlibdoc.who.int/publications/2011/9789240685215_eng.pdf?ua=1. Accessed 30 Oct 2014

Marco Fasciglione is Researcher at the Institute for International Legal Studies (ISGI-CNR), Naples. 